Making the Palace Machine Work 


\section{Asian History}

The aim of the series is to offer a forum for writers of monographs and occasionally anthologies on Asian history. The series focuses on cultural and historical studies of politics and intellectual ideas and crosscuts the disciplines of history, political science, sociology and cultural studies.

\section{Series Editor}

Hans Hågerdal, Linnaeus University, Sweden

Editorial Board

Roger Greatrex, Lund University

David Henley, Leiden University

Ariel Lopez, University of the Philippines

Angela Schottenhammer, University of Salzburg

Deborah Sutton, Lancaster University 


\title{
Making the Palace Machine Work
}

\author{
Mobilizing People, Objects, and Nature \\ in the Qing Empire
}

\author{
Edited by \\ Martina Siebert, \\ KaiJun Chen, and \\ Dorothy Ko
}


Cover illustration: Artful adaptation of a section of the $175^{\circ}$ Complete Map of Beijing of the Qianlong Era (Qianlong Beijing quantu 乾隆北京全圖) showing the Imperial Household Department by Martina Siebert based on the digital copy from the Digital Silk Road project (http://dsr.nii.ac.jp/toyobunko/II-11-D-802, vol. 8, leaf 7)

Cover design: Coördesign, Leiden

Lay-out: Crius Group, Hulshout
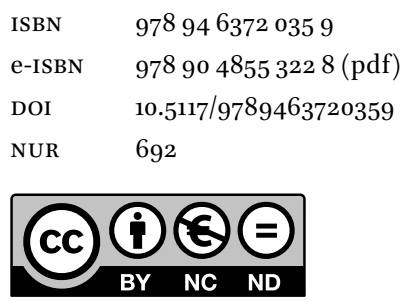

Creative Commons License CC BY NC ND (http://creativecommons.org/licenses/by-nc-nd/3.o)

@ The authors / Amsterdam University Press B.V., Amsterdam 2021

Some rights reserved. Without limiting the rights under copyright reserved above, any part of this book may be reproduced, stored in or introduced into a retrieval system, or transmitted, in any form or by any means (electronic, mechanical, photocopying, recording or otherwise). 